\title{
Traveltimes of Flood Waves on the New River Between Hinton and Hawks Nest, West Virginia
}

By D. H. Appel

Prepared in cooperation with the National Park Service and the West Virginia Geological and Economic Survey 
UNITED STATES DEPARTMENT OF THE INTERIOR

JAMES G. WATT, Secretary

GEOLOGICAL SURVEY

Dallas L. Peck, Director



For sale by Distribution Branch

Text Products Section

U.S. Geological Survey

604 South Pickett Street

Alexandria, Virginia 22304

\section{Library of Congress Cataloging in Publication Data}

Appel, D. H.

Traveltimes of flood waves on the New River between

Hinton and Hawks Nest, West Virginia.

(U.S. Geological Survey water-supply paper; 2225)

Bibliography: $p$.

Supt. of Docs. no.: I 19.13:

1. Flood routing. 2. New River (N.C.-W. Va.)-Floods. 3. Floods-West Virginia. I. United States. National Park Service. II. West Virginia Geological and Economic Survey. III. Title. IV. Series: Geological Survey water-supply paper; 2225. 


\section{CONTENTS}

$\begin{array}{lr}\text { Abstract } & 1 \\ \text { Introduction } & 2 \\ \text { History of the area } & 4 \\ \text { General geologic history } & 4 \\ \text { Recent history } & 4 \\ \text { River-flow characteristics } & 5 \\ \text { Monthly and daily flows } & 5 \\ \text { Traveltime } & 7 \\ \text { Thurmond gaging station } & 11 \\ \text { Fayette gage } & 12 \\ \text { Summary } & 12\end{array}$

\section{FIGURES}

1. General location map 2

2. Map of study area 3

3. Generalized stratigraphic column for the New River Gorge 4

4. Photograph of small-town depot in Gorge 5

5. Photograph of coal miners at Elverton 6

6. Bar graph of mean-monthly flows of the New River at Hinton
from 1948 to 1979

7. Bar graph of daily-flow variance for the New River at Hinton
from 1948 to 1979

8. Graph showing traveltimes of flood waves at selected stream-
flows in the New River between Hinton and Hawks Nest

9. Graph showing traveltimes of flood waves from Hinton to selected communities in the New River Gorge

10. River stage-streamflow rating curve for the New River at Thurmond

11. River stage-streamflow rating curve for the New River at the Fayette bridge

12. Curve relating river stage at Thurmond and Fayette 14

TABLES

1. New River miles 11

2. River stage-streamflow rating table for the New River at Thurmond 12

Cover photograph: Whitewater boating, one of the New River's main attractions. (Photograph from the National Park Service collection.) 


\section{Traveltimes of Flood Waves on the New River Between Hinton and Hawks Nest, West Virginia}

\author{
By D. H. Appel
}

\section{Abstract}

The New River Gorge National River's [a 51-mile segment of the New River between Hinton and Fayette (an abandoned community), W. Va.] main attraction is a combination of scenic wilderness, fishing, cultural resources, and whitewater boating. However, recreational quality, safety, and use of the river depends in part upon the amount and fluctuations in streamflow, manmade and natural. During 1981 and 1982, the U.S. Geological Survey found that the flood wave travels at an average speed of 6.8 miles per hour when streamflow is 15,000 cubic feet per second and 3.5 miles per hour when streamflow is 2,200 cubic feet per second. Curves have been developed to estimate traveltimes between any two points within the National River jurisdiction.

The gaging station at Thurmond, installed as part of this study, can be called by telephone, (304) 465-0493, to determine river stage. The river stage can be converted to streamflow and traveltimes.

\section{INTRODUCTION}

The New River flows northward from its headwaters in North Carolina, through western Virginia, and into south-central West Virginia, where it joins the Gauley River at Gauley Bridge to form the Kanawha River (fig. 1). The New River Gorge National River was established by Public Law 95-625 on November 10, 1978 , and falls within the jurisdiction of the U.S. Department of Interior, National Park Service (NPS). The NPS is responsible for conserving the outstanding natural, scenic, and historical values and objects and preserving a segment of the New River in West Virginia as a free-flowing stream for the enjoyment and benefit of present and future generations. This report, prepared for the NPS, summarizes the results of a study of the time of travel of flood waves on the 56-mile (mi) reach of river between Hinton and Hawks Nest, W. Va. (fig. 2). The New River Gorge National River falls within this reach of the river. The National River's main attraction is a combination of scenic wilderness, fishing, and excellent whitewater boating. Approximately 60,000 people rafted on the 34-mi reach of river between Prince and Hawks Nest, W. Va., and about 100,000 hours (hr) were expended by anglers between Bluestone Dam and Meadow Creek in 1980 (fig. 2). The recreational quality and safety depends in part upon the regulated flow from Bluestone Dam and unregulated flow from the Greenbrier River.
The Water Resources Division of the U.S. Geological Survey, in cooperation with the National Park Service and the West Virginia Geological and Economic Survey, has studied the time of travel of flood waves on the New River from Hinton to Hawks Nest. Flood waves, as used in this report, refer to any rapid rise in river stage caused by natural runoff from storms and releases from Bluestone Dam. Flood-wave traveltimes were determined by following waves from controlled releases from Bluestone Dam downstream to selected observation points, bridges, and gaging stations where temporary staff gages had been established. The results of this study can be used to predict whitewater conditions in the boating and recreational areas. River miles for all bridges and other selected observation points above Gauley Bridge are listed in table 1 . Selected mileages are shown on figure 2 . Curves presented in this report apply to wave traveltime only. They do not apply to the traveltime of dissolved contaminants that may be accidently spilled or discharged into the river.

The West Virginia Geological and Economic Survey provided information used in the geologic section of this report, and the U.S. Army Corps of Engineers, Huntington District, provided the special flow conditions for the study by regulating outflow from Bluestone Dam.

Table 1.-New River miles

\begin{tabular}{|c|c|}
\hline Location & $\begin{array}{c}\text { Miles upstream } \\
\text { from Gauley Bridge }\end{array}$ \\
\hline \multicolumn{2}{|l|}{ Confluence of New and Gauley } \\
\hline Rivers at Gauley Bridge--_- & 0.0 \\
\hline Highway 16 bridge at Cotton Hill ------ & 5.7 \\
\hline C\&O Railroad bridge at Hawks Nest----- & 7.6 \\
\hline \multicolumn{2}{|l|}{ Highway 82 bridge at Fayette } \\
\hline (Staff Gage) - & 12.3 \\
\hline \multicolumn{2}{|l|}{ C\&O Railroad bridge upstream from } \\
\hline Caperton-----_- & 18.3 \\
\hline \multicolumn{2}{|l|}{ C\&O Railroad/Highway bridge at } \\
\hline Thurmond-_-_- & 25.9 \\
\hline USGS gaging station (Thurmond) ------ & 26.0 \\
\hline Highway 25 bridge at Stone Cliff-_-_-_- & 27.4 \\
\hline Highway 41 bridge at Prince---_------- & 39.8 \\
\hline C\&O Railroad bridge at Prince ------- & 39.9 \\
\hline Meadow Creek (no bridge) - & 50.9 \\
\hline Sandstone (no bridge) - & 54.3 \\
\hline Highway 20 bridge at Hinton ---------- & 63.5 \\
\hline USGS gaging station (Hinton) - - & 63.6 \\
\hline Highway 3 bridge at Bellepoint -------- & 65.2 \\
\hline Bluestone Dam-_- & 65.9 \\
\hline
\end{tabular}




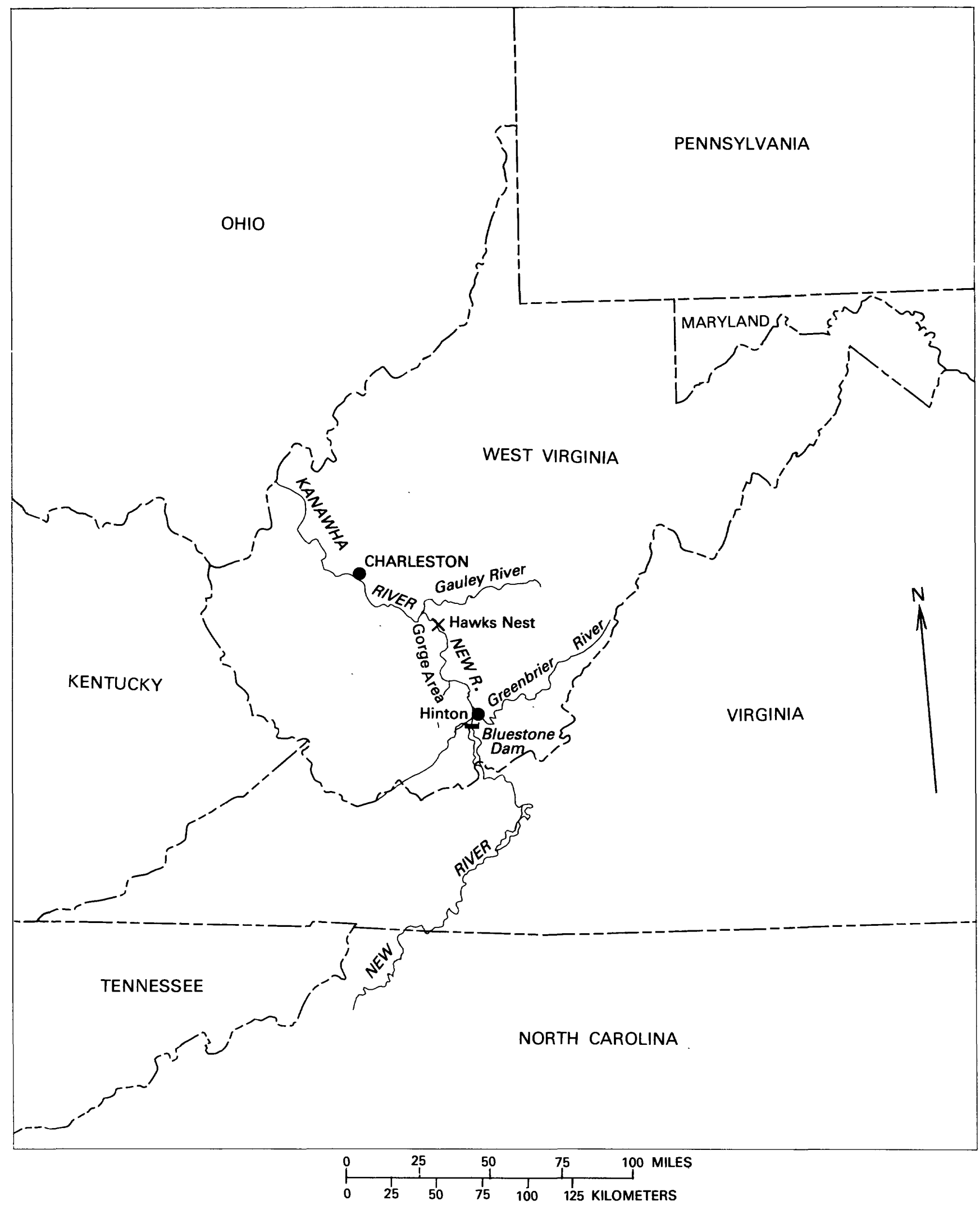

Figure 1. General location of the New River. 


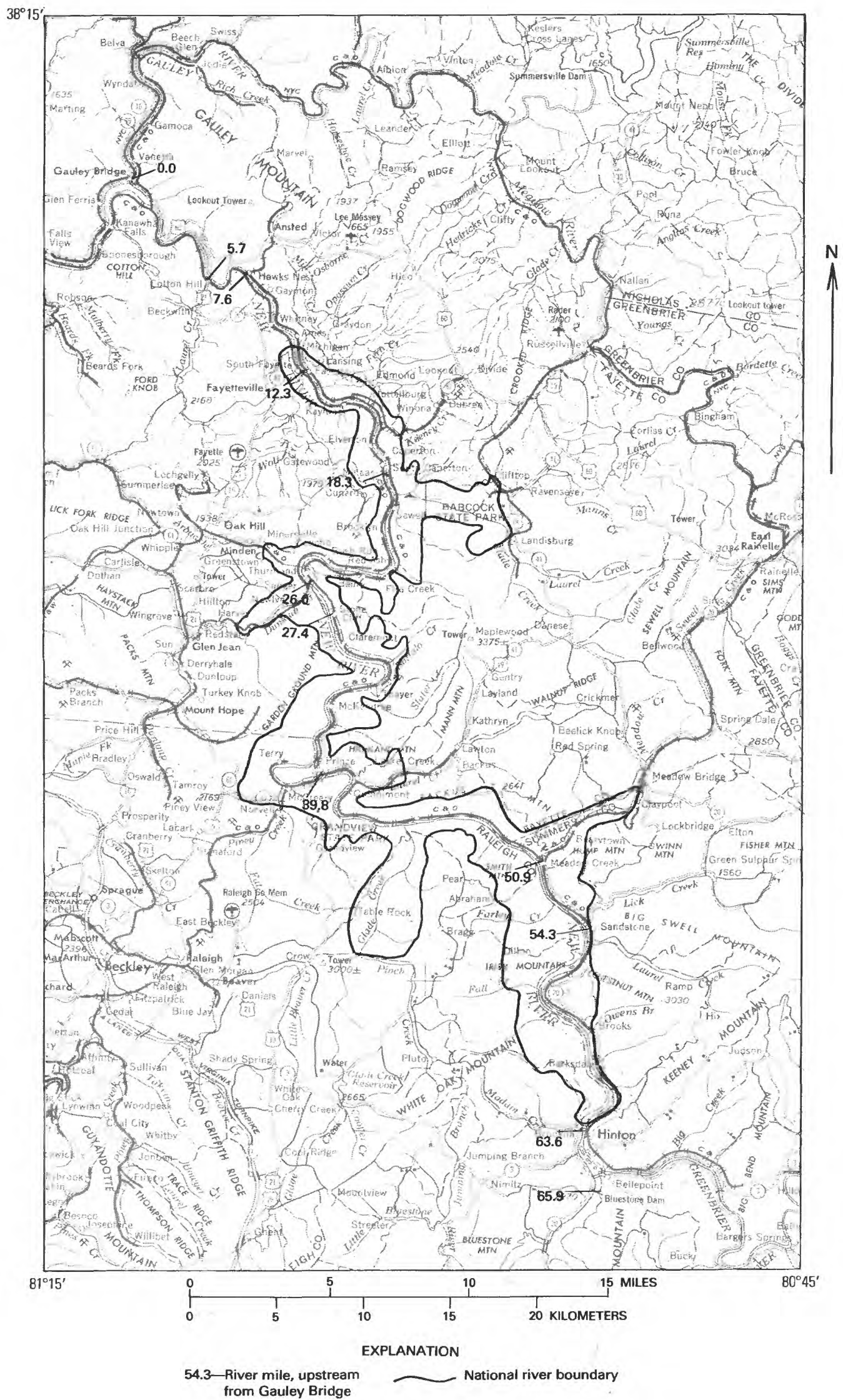

Figure 2. Study area and New River Gorge National River. 


\section{HISTORY OF THE AREA}

\section{General Geologic History}

The New River has cut the gorge from Hinton to Gauley Bridge, exposing rocks that permit a view and interpretation of the local geology. The river gradually drops 750 feet $(\mathrm{ft})$ in elevation between Hinton and Gauley Bridge (12 ft/mi). The river flows northward; the average elevation of the surrounding ridges decreases northward; and the rocks dip northward. As the inclination or dip of the rock is greater than the fall of the river, each successive layer of rock disappears under the river as one travels northward.

The rocks exposed in the gorge (fig. 3) are categorized into two groups: the oldest is of Mississippian age (the Mauch Chunk Group) and the youngest is of Pennsylvanian age (the Pottsville Group). The Pottsville Group is distinctive because it contains many of the commercial coal beds in West Virginia. Figure 3 shows where selected communities are situated with respect to the stratigraphic column exposed along the river.

Total thickness of the exposed rocks is about 4,000 $\mathrm{ft}$, but this is not to be confused with the maximum depth of the gorge, which is about $1,600 \mathrm{ft}$. Numerous studies worldwide indicate that it probably took 7 million to 10 million years $(\mathrm{yr})$ to deposit these $4,000 \mathrm{ft}$ of sand, mud, coal, and sediments that were later consolidated into rocks. Thus, each foot of rock took approximately 2,000 yr to accumulate. The formations exposed in the gorge span a time in the Earth's history from about $\mathbf{3 2 0}$ million to 330 million yr ago.

The dominant rocks in the gorge are nonmarine shale and sandstone. These are clastic rocks derived from the deposition of sediments eroded from preexisting rocks. Some are coarse grained, such as the Princeton Formation, whereas others, such as shale beds, are very fine grained. The coal, on the other hand, was formed from the deposition and compaction of dead plants and trees, some of which can still be identified in the coal. The characteristics of the rocks and fossils indicate the depositional environment and, to some degree, the source material of the clastic material. A highland to the southeast, approximately where the Blue Ridge Mountains are today, was the major source of sediments for these rocks.

The information presented in this section was based on written communication from Peter Lessing of the West Virginia Geological and Economic Survey (1982).

More detailed geologic information of the area is available in reports published by the West Virginia Geological and Economic Survey and from the U.S. Geological Survey.

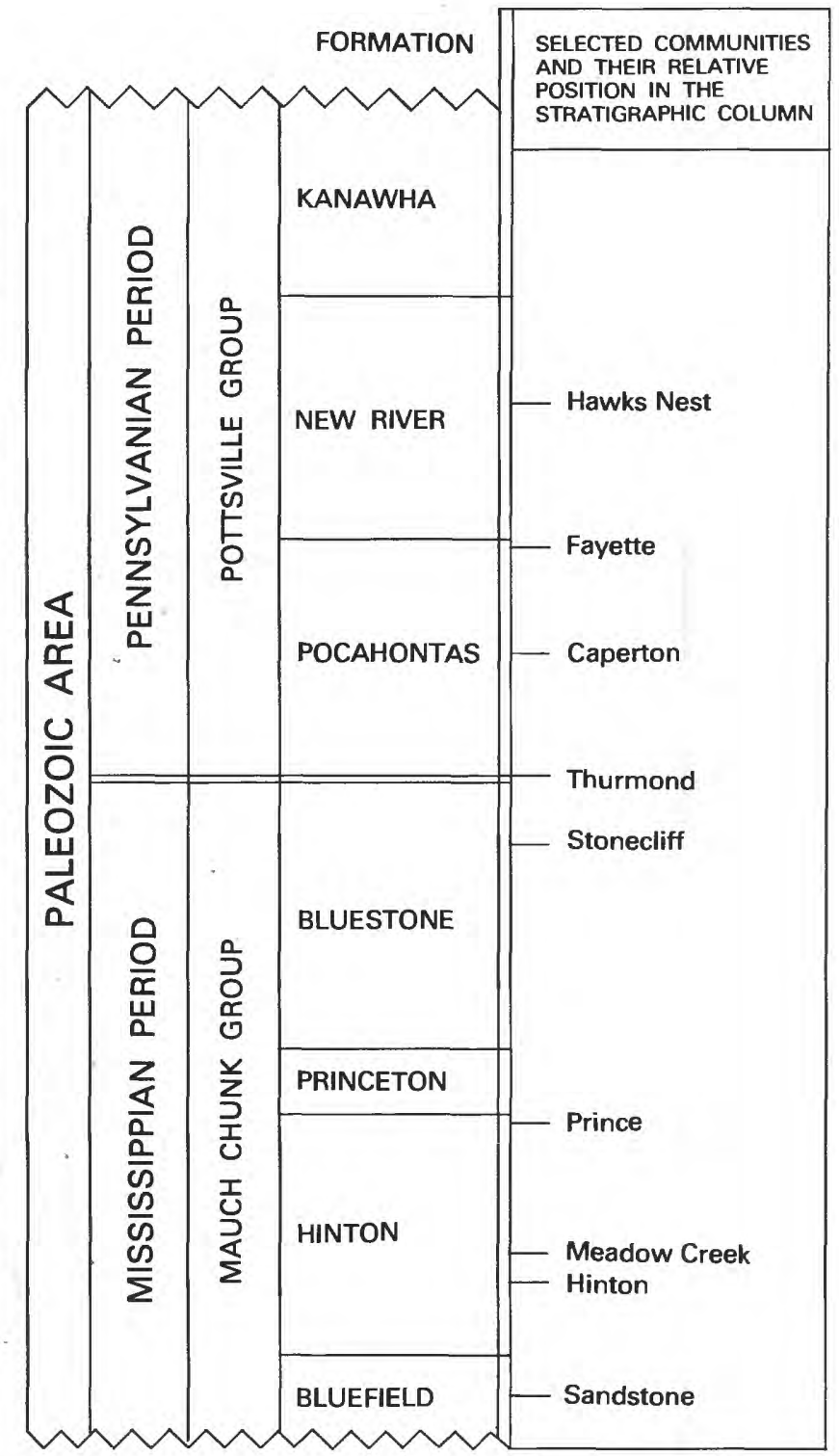

Figure 3. Generalized stratigraphic column for the New River Gorge, W. Va. (Modified from Peter Lessing, written commun., 1982.)

\section{Recent History}

The New River Gorge was discovered by early settlers in approximately 1671 . By the 1800 's, settlers numbered in the few thousands. From 1869 to 1873, the Chesapeake and Ohio Railroad constructed a main line along the bottom of the gorge for hauling coal. The railroad opened the valuable coal fields for commercial development, and over a dozen small towns were built in the gorge. The railroad depot at Fire Creek (fig. 4) was typical in the area.

Thurmond is one of those towns still in existence. Originally, it had no roads leading to it, and the railroad 




Figure 4. Small-town depot in gorge. (Photograph from National Park Service Collection.)

tracks were the main street. This town was reportedly the commercial and social center of the New River coal fields. In the 1930's, business began moving from the gorge to the towns on the plateau, causing the decline and eventual abandonment of most of the gorge's boom towns. The peak year for coal production was 1947, when approximately 4,800 miners were working in the gorge (fig. 5). In contrast, only about 600 miners worked the same area in 1968 because of increased mechanization in the mines and a depressed coal market. As mining and population decreased, the economy correspondingly decreased. Thousands of acres of farmland have reverted to forest, and the area is now in a more natural state than it was 30 years ago.

More detailed information concerning the history of the New River Gorge can be obtained from the National Park Service and the West Virginia Department of Culture and History, Archives and History Branch.

\section{RIVER-FLOW CHARACTERISTICS}

\section{Monthly and Daily Flows}

The best whitewater boating in this reach of the New River is when the river flows between 3,000 and 15,000 cubic feet per second $\left(\mathrm{ft}^{3} / \mathrm{s}\right)$. The whitewaterboating season is generally between April and October. The bar graph (fig. 6) shows the mean-monthly flows of the New River at Hinton (mile 63.6) from 1948 to 1979. Flow characteristics at Hinton are representative of those at Thurmond. The graph also shows general riverflow conditions at Hinton; maximum flow is from February to April, whereas minimum flow is from July to September. Note that monthly-mean flows fluctuate widely from year to year. For example, monthly-mean flow in March ranged from 7,380 ft $3 / \mathrm{s}$ in 1976 to 32,400 


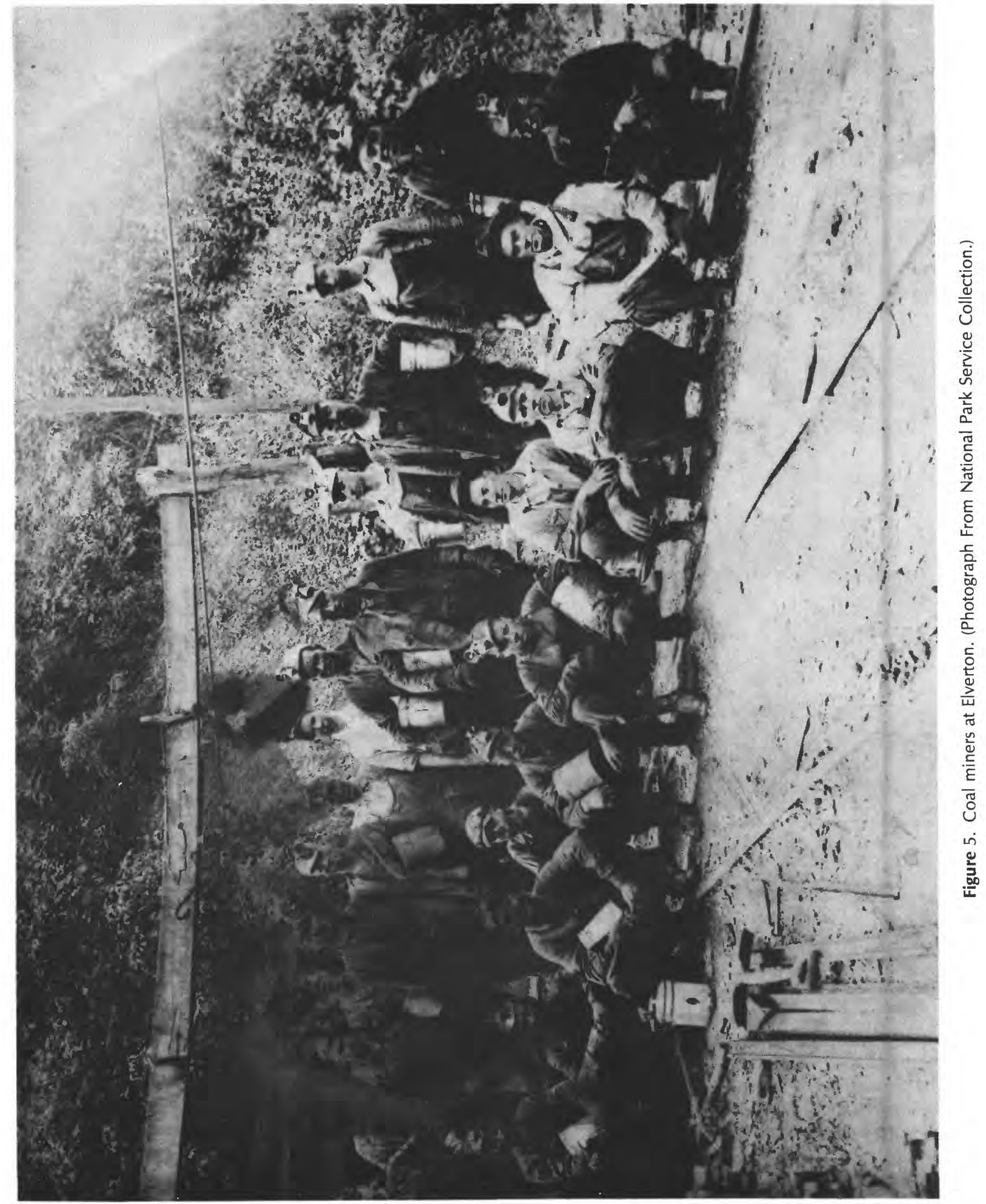

6 Traveltimes of Flood Waves on the New River Between Hinton and Hawks Nest, West Virginia 


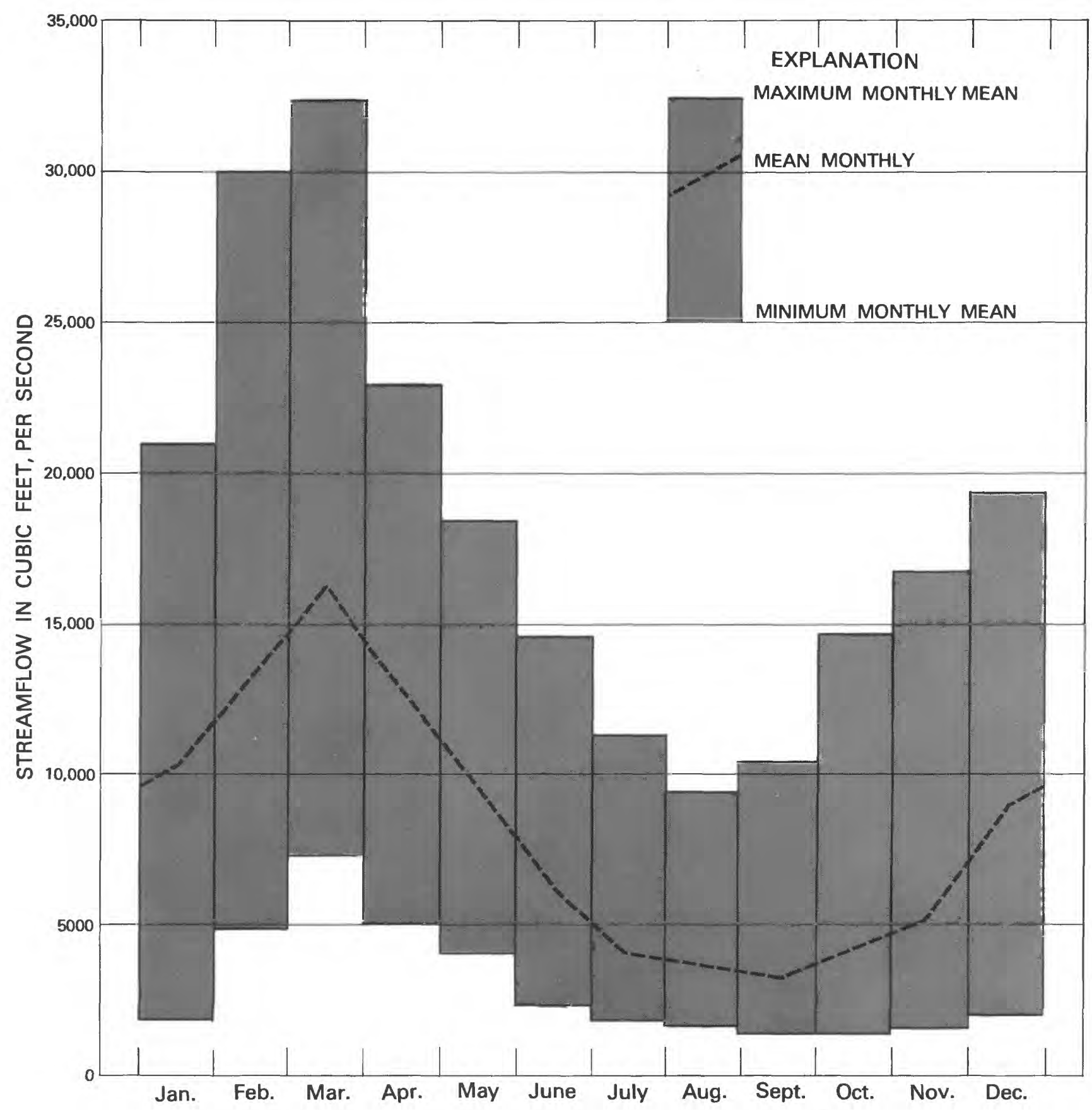

Figure 6. Mean-monthly flows of the New River at Hinton from 1948 to 1979.

$\mathrm{ft}^{3} / \mathrm{s}$ in 1955; the mean-monthly flow in March from 1948 to 1979 was $16,200 \mathrm{ft}^{3} / \mathrm{s}$.

The daily-mean flows can be expected to fluctuate even more widely than the monthly-mean flows. Figure 7 shows the average number of days per month that flow either exceeds $16,000 \mathrm{ft}^{3} / \mathrm{s}$ or is less than $2,800 \mathrm{ft}^{3} / \mathrm{s}$ at Hinton from 1948 to 1979.

\section{Traveltime}

The stage (height of water surface above some arbitrary datum) and flow of the New River in the gorge are affected by operation of Bluestone Dam on the New River and unregulated flow from the Greenbrier River. 


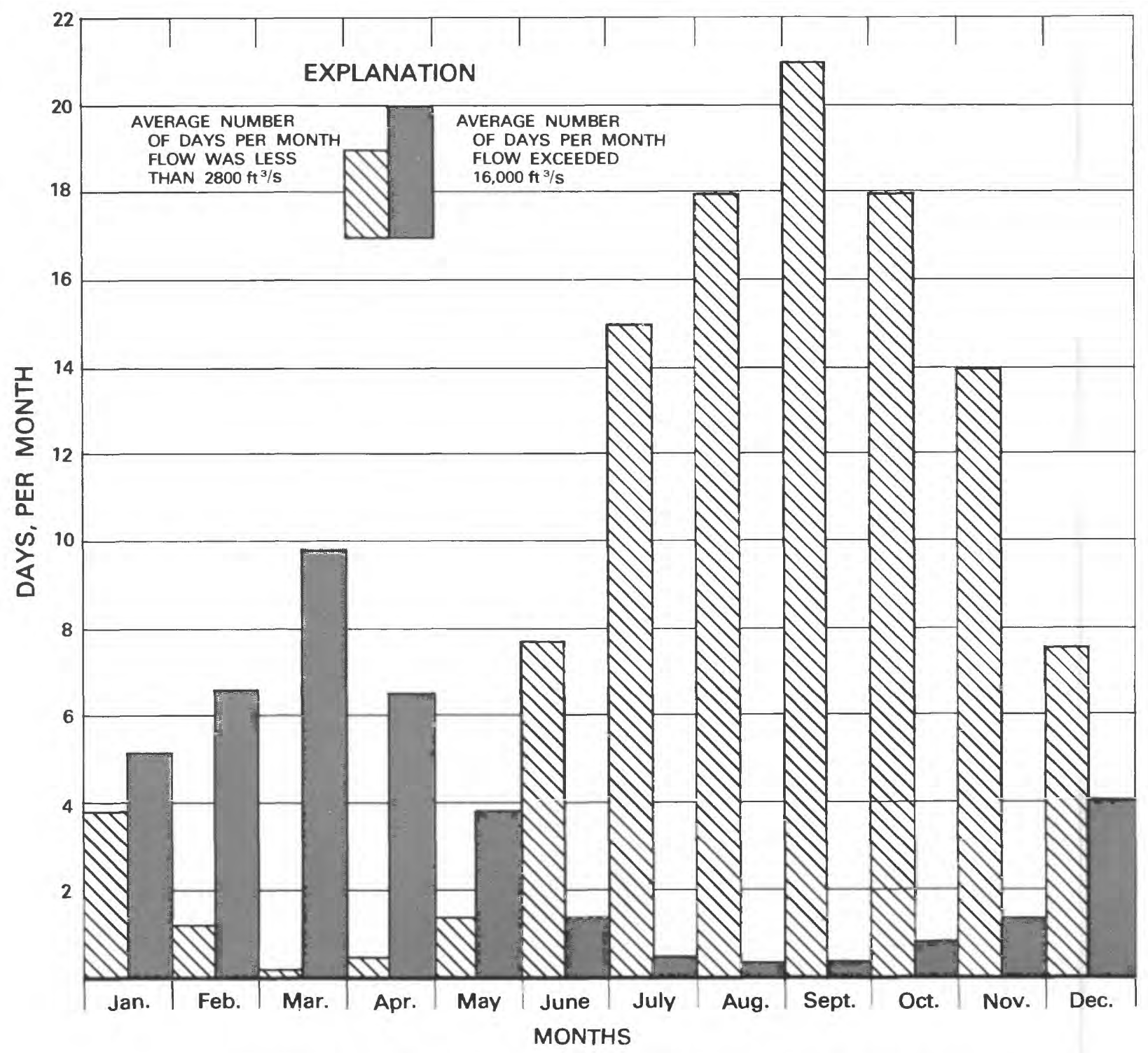

Figure 7. Daily-flow variance of the New River at Hinton from 1948 to 1979.

River stage and flow can change rapidly from rainfall and from operation of the dam. Therefore, for recreation and safety, it is important to users of the river to know the approximate time a flood wave takes to travel down the river.

Traveltimes of flood waves from Bluestone Dam to Hawks Nest were determined by following controlled releases from the dam as they moved downstream through the New River Gorge. Traveltime data were collected at seven sites for two flow rates $(2,200$ and 15,000 $\mathrm{ft}^{3} / \mathrm{s}$ ) from November 1981 to February 1982. Traveltimes of several selected waves were also computed from gaging-station records from Hinton and Thurmond.

The time for a flood wave to move from Hinton (mile 63.6) to any point as far downstream as Fayette at four different flow rates and to Hawks Nest at 15,000 $\mathrm{ft}^{3} / \mathrm{s}$ is shown in figure 8. Traveltimes for streamflows less than $15,000 \mathrm{ft}^{3} / \mathrm{s}$ between Fayette and Hawks Nest were not determined because the operation of the powerplant and dam at Hawks Nest distorts the flood wave. Figure 8 can be used to compute approximate traveltimes between any two points in the 51-mi reach of river between Hinton and Fayette at flows between 2,200 and $15,000 \mathrm{ft}^{3} / \mathrm{s}$. When the streamflow is 15,000 $\mathrm{ft}^{3} / \mathrm{s}$, a flood wave travels between Hinton and Fayette in 7.5 hours at an average speed of $6.8 \mathrm{mi} / \mathrm{hr}$. However, when streamflow is $2,200 \mathrm{ft}^{3} / \mathrm{s}$, the average speed is only $3.5 \mathrm{mi} / \mathrm{hr}$.

Figure 9 shows the time for a wave to travel from Hinton to Sandstone (mile 54.3), Meadow Creek (mile 


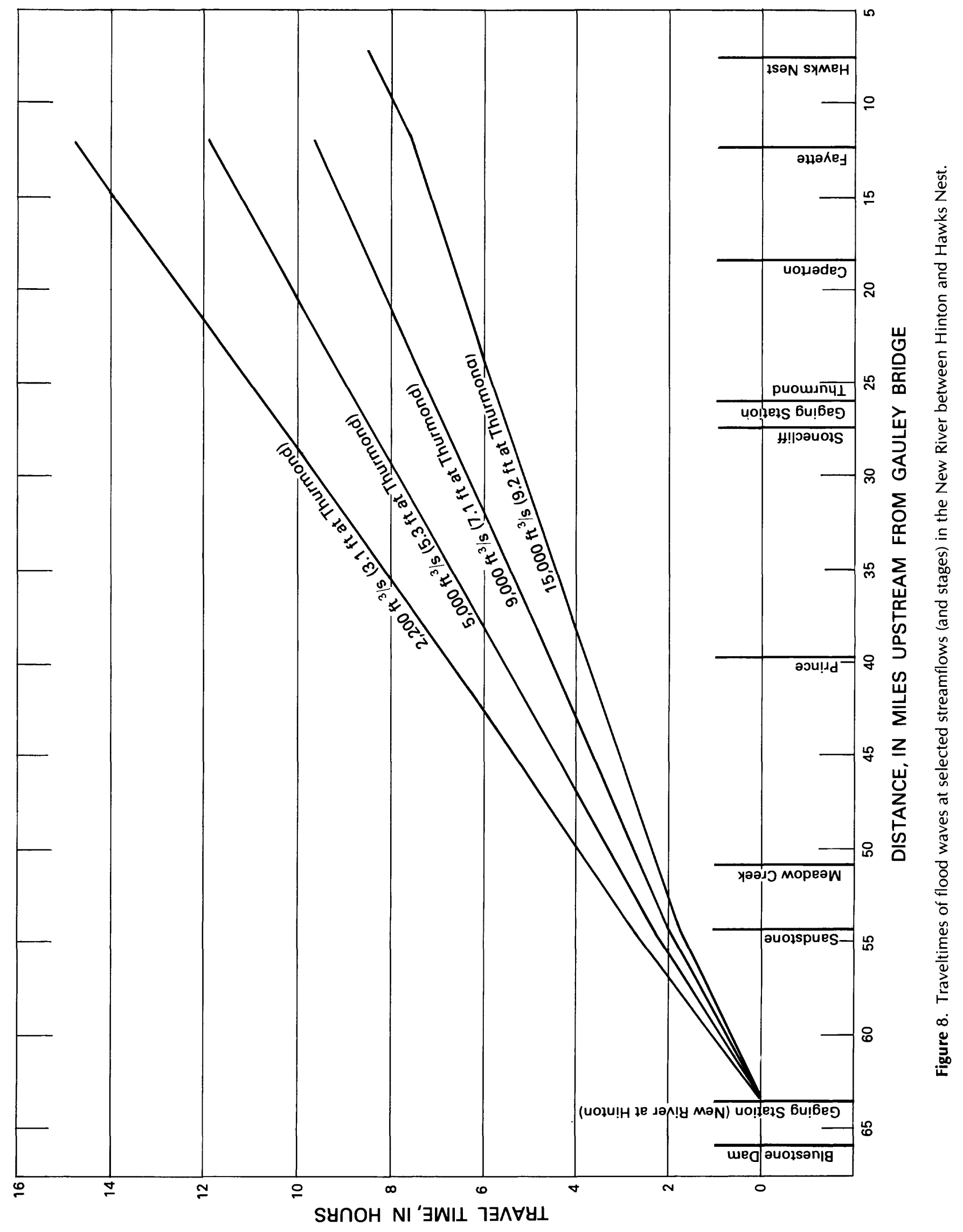




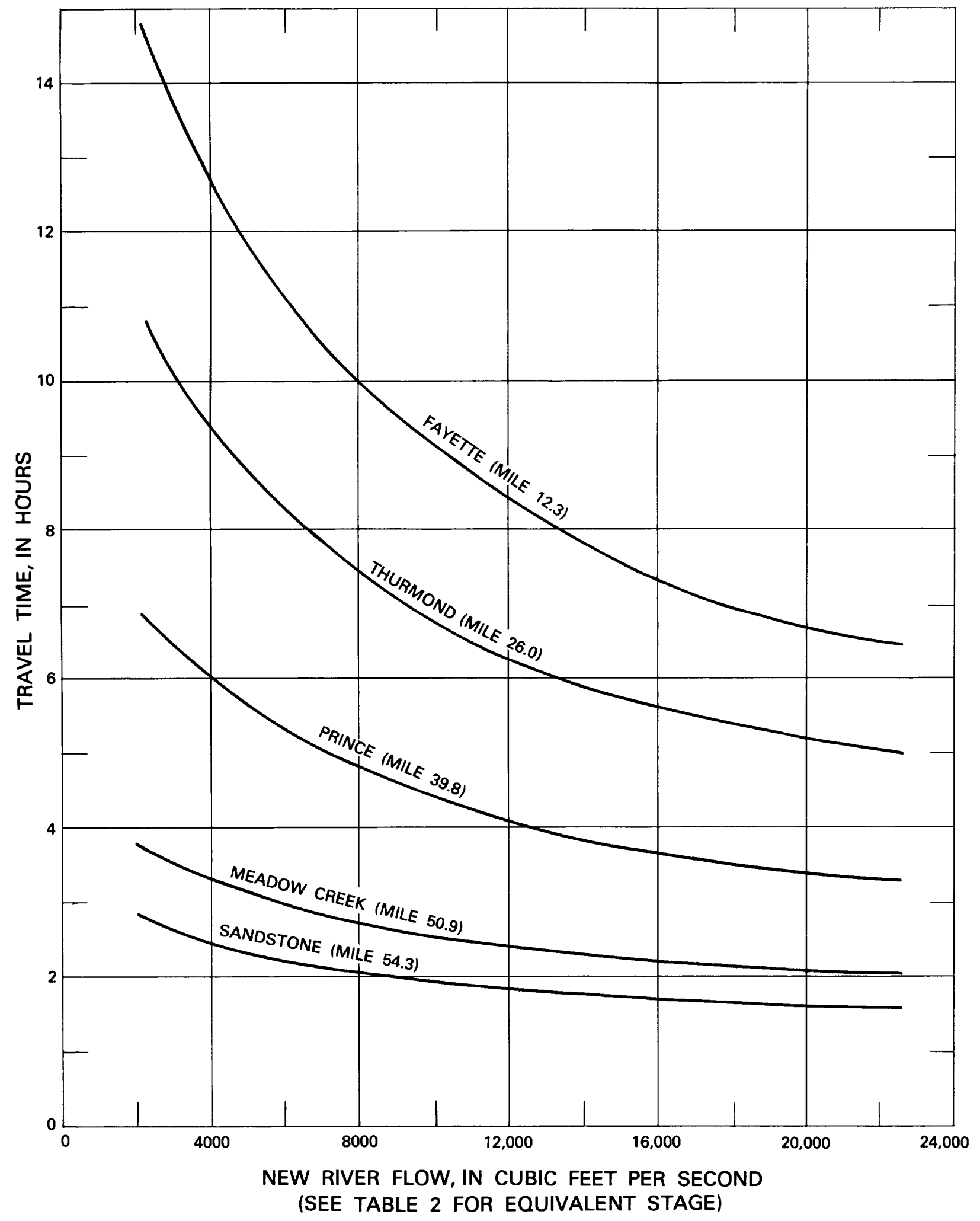

Figure 9. Traveltimes of flood waves from Hinton to selected communities in the New River Gorge. 
50.9), Prince (mile 39.8), Thurmond (mile 26.0), and Fayette (mile 12.3).

Note that the time-of-travel information in this report is for flood waves only. It is not the traveltime of a contaminant that may be accidentally spilled or discharged into the river.

\section{Thurmond Gaging Station}

A gaging station was installed at Thurmond (mile 26.0) as part of this study because most boat trips begin near this point. Equipment at the gaging station continuously records the river stage or height. The station is also equipped with a telemeter, which is an instrument which, when called by telephone, will transmit riverstage information as a series of beeps. The streamflow or discharge of the river is periodically measured by a current meter at the Stone Cliff highway bridge (mile 27.4) upstream from Thurmond. Figure 10 shows the relation between streamflow, in cubic feet per second, and river stage, in feet, at the New River at Thurmond. The curve can be used to determine river flow at any stage. An example of the use of figure 10 is as follows: enter the river stage on the vertical scale at $6.0 \mathrm{ft}$, move horizontally to the curve, and then move vertically down to the streamflow scale at $6,300 \mathrm{ft}^{3} / \mathrm{s}$.

Table 2 is simply a tabular display of the rating curve shown in figure 10. Minor changes in the river stage-streamflow relationship may occur as a result of extreme floods; however, traveltimes will be relatively unaffected. If actual streamflow is needed, contact the National Park Service, National River Headquarters, or the U.S. Geological Survey in Charleston, W. Va.

As an aid to the NPS, rafters, and fishermen, river stage and (or) flow at Thurmond can now be determined by telephoning the telemeter (304) 465-0493. The telephone signal will consist of four sets of beeps, and river stage can be determined by counting the number of beeps in each set. The number of beeps in each set correspond to the four digits that constitute river stage. Examples are as follows:

\begin{tabular}{|c|c|}
\hline River stage & Telephone transmission \\
\hline $08.21 \cdots$ & $\begin{array}{l}\text {-(0) one long beep, pause } \\
\text { (8) eight short beeps, pause } \\
\text { (2) two short beeps, pause } \\
\text { (1) one short beep, circuit disconnects }\end{array}$ \\
\hline $11.20-\cdots$ & $\begin{array}{l}\text { (1) one short beep, pause } \\
\text { (1) one short beep, pause } \\
\text { (2) two short beeps, pause } \\
\text { (0) one long beep, circuit disconnects }\end{array}$ \\
\hline
\end{tabular}

Thus, river flow can be determined by the river stage information (above) and the rating curve shown in figure 10 and the tabular display in table 2.

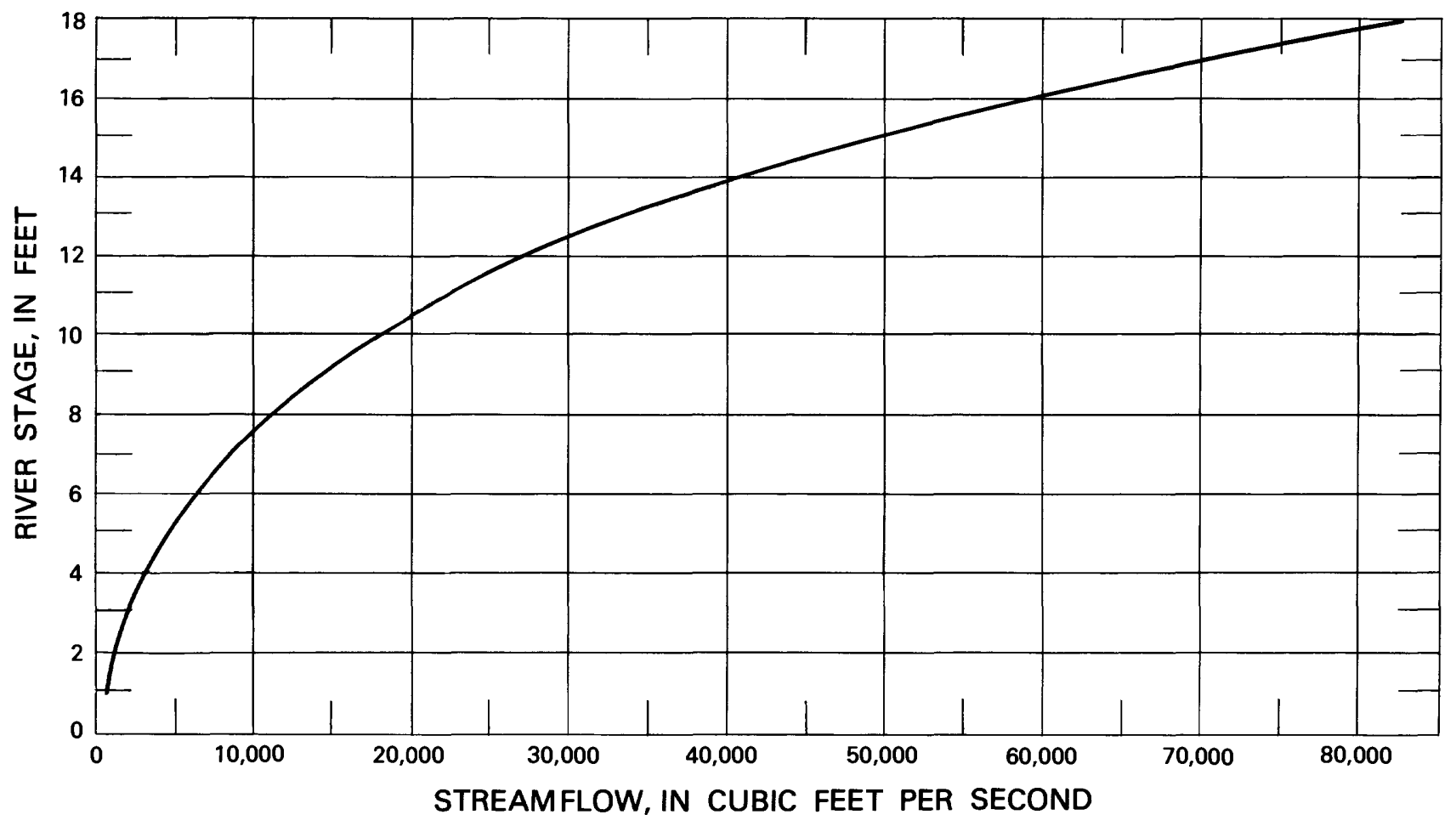

Figure 10. River stage-streamflow rating curve for the New River at Thurmond. 
Table 2.-River stage-streamflow rating table for the New River at Thurmond

\begin{tabular}{|c|c|c|c|c|c|c|c|c|c|c|}
\hline \multirow{2}{*}{$\begin{array}{l}\text { River stage } \\
\text { (ft) }\end{array}$} & \multicolumn{10}{|c|}{$\begin{array}{c}\text { Streamflow } \\
\left(\mathrm{ft}^{3} / \mathrm{s}\right)\end{array}$} \\
\hline & 0.0 & 0.1 & 0.2 & 0.3 & 0.4 & 0.5 & 0.6 & 0.7 & 0.8 & 0.9 \\
\hline 0.00 & & & & & 250 & 295 & 340 & 390 & 445 & 505 \\
\hline 1.00 & 570 & 635 & 700 & 765 & 830 & 895 & 960 & 1030 & 1100 & 1170 \\
\hline 2.00 & 1240 & 1320 & 1400 & 1480 & 1560 & 1650 & 1740 & 1830 & 1920 & 2010 \\
\hline 3.00 & 2100 & 2190 & 2280 & 2380 & 2480 & 2580 & 2680 & 2800 & 2920 & 3040 \\
\hline 4.00 & 3160 & 3280 & 3400 & 3520 & 3640 & 3780 & 3920 & 4060 & 4200 & 4340 \\
\hline 5.00 & 4500 & 4660 & 4820 & 4980 & 5160 & 5340 & 5520 & 5700 & 5900 & 6100 \\
\hline 6.00 & 6300 & 6500 & 6700 & 6900 & 7150 & 7400 & 7650 & 7900 & 8150 & 8400 \\
\hline 7.00 & 8650 & 8900 & 9150 & 9400 & 9650 & 9900 & 10200 & 10500 & 10800 & 11100 \\
\hline 8.00 & 11400 & 11700 & 12000 & 12300 & 12600 & 12900 & 13200 & 13500 & 13800 & 14100 \\
\hline 9.00 & 14400 & 14700 & 15000 & 15300 & 15600 & 15900 & 16200 & 16600 & 17000 & 17400 \\
\hline 10.00 & 17800 & 18200 & 18600 & 19000 & 19400 & 19800 & 20200 & 20600 & 21000 & 21400 \\
\hline 11.00 & 21800 & 22300 & 22800 & 23300 & 23800 & 24300 & 24800 & 25300 & 25800 & 26300 \\
\hline 12.00 & 26800 & 27400 & 28000 & 28600 & 29200 & 29800 & 30400 & 31100 & 31800 & 32500 \\
\hline 13.00 & 33200 & 33900 & 34600 & 35300 & 36000 & 36700 & 37400 & 38100 & 38900 & 39700 \\
\hline 14.00 & 40500 & 41300 & 42100 & 42900 & 43700 & 44500 & 45400 & 46300 & 47200 & 48100 \\
\hline 15.00 & 49000 & 50000 & 51000 & 52000 & 53000 & 54000 & 55000 & 56000 & 57000 & 58000 \\
\hline 16.00 & 59000 & 60100 & 61200 & 62300 & 63400 & 64500 & 65600 & 66700 & 67800 & 68900 \\
\hline 17.00 & 70000 & 71200 & 72400 & 73600 & 74800 & 76000 & 77200 & 78500 & 79800 & 81100 \\
\hline 18.00 & 82400 & & & & & & & & & \\
\hline
\end{tabular}

\section{Fayette Gage}

A staff gage painted on the pier of the Highway 82 bridge, which crosses the New River at Fayette, has had widespread use as an aid to boaters in determining streamflow in the lower reach of the gorge. As part of this study, the river stage-streamflow relationship was determined for this gage (fig. 11). To use the curve in figure 11 , the gage at the bridge must be read and then converted to flow, as explained earlier in the example, for use of figure 10. The gage at Fayette can be used to determine river conditions at Fayette only. This gage cannot provide information on water levels upstream from Fayette in the boating reach.

To assist boaters who have been using the Fayette gage in making the transition to the gage at Thurmond, a curve has been drawn relating the stage at Fayette and the stage at Thurmond (fig. 12). The gages at Fayette and Thurmond are each at a different datum, and, because the hydraulic properties and channel shapes at the two sites are different, the gages cannot be set to read the same at all stages.

\section{SUMMARY}

The New River Gorge National River area has had boom towns in the past but today is more "natural" than it was $30 \mathrm{yr}$ ago. The area is heavily used by whitewater enthusiasts, fishermen, and sightseers.

Recreational quality, safety, and use of the River for whitewater boating depends upon streamflow and fluctuations in streamflow, manmade and natural. The traveltime of flood waves down the stream depends upon streamflow-the greater the flow, the faster the flood wave travels. Flood-wave time-of-travel curves were developed with traveltime data from controlled streamflow releases from Bluestone Dam upstream from Hinton. The curves are useful for estimating flood-wave traveltimes between any two points and for determining boating conditions within the New River Gorge National River area.

The gaging station at Thurmond, installed as part of this study, can be reached by telephone, (304) 465-0493, to determine river stage. The river stage can, thus, be converted to streamflow and associated traveltimes by appropriate graphs from this report. 


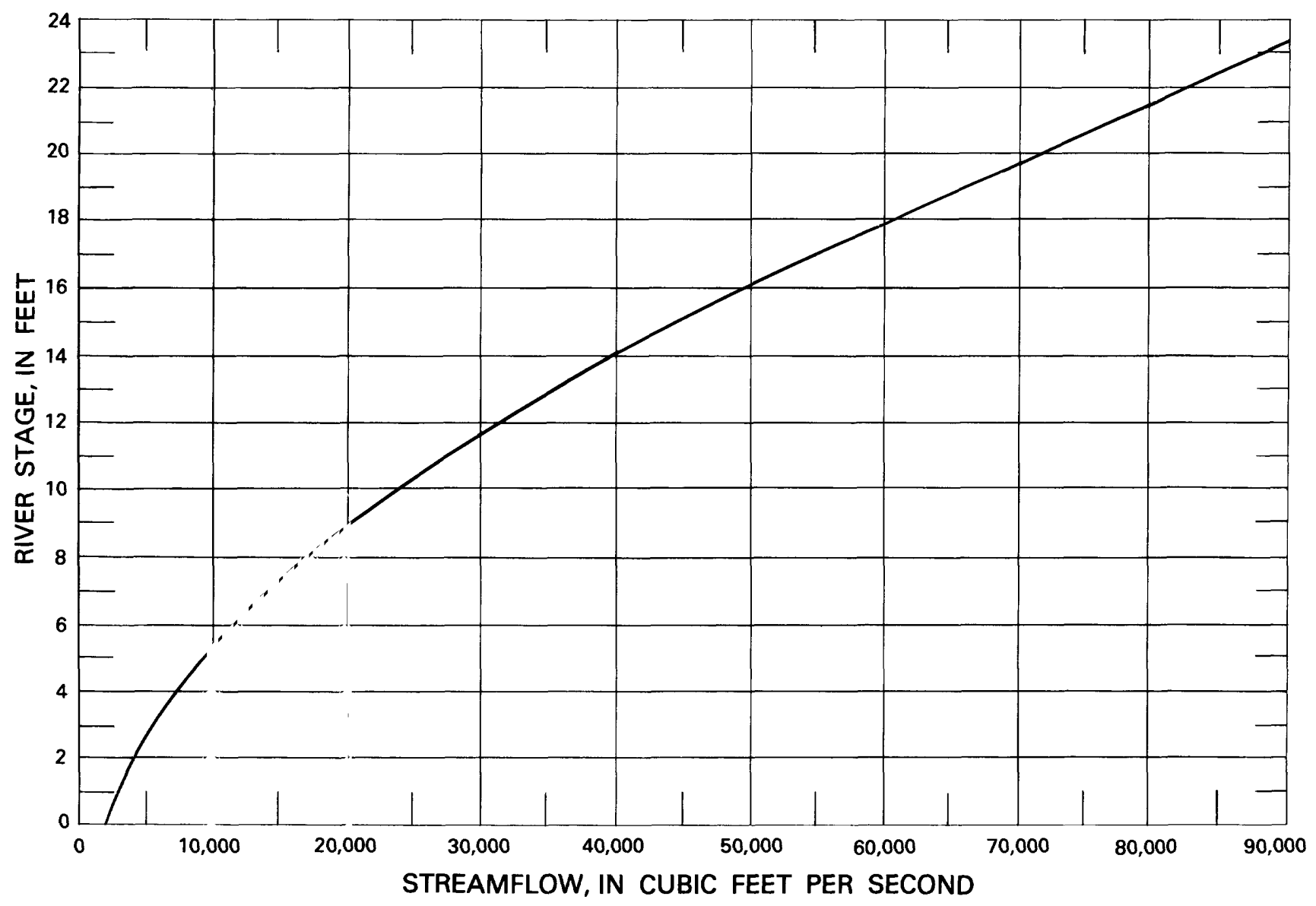

Figure 11. River stage-streamflow rating curve for the New River at the Fayette (Highway 82 ) bridge. (Staff gage on pier.) 


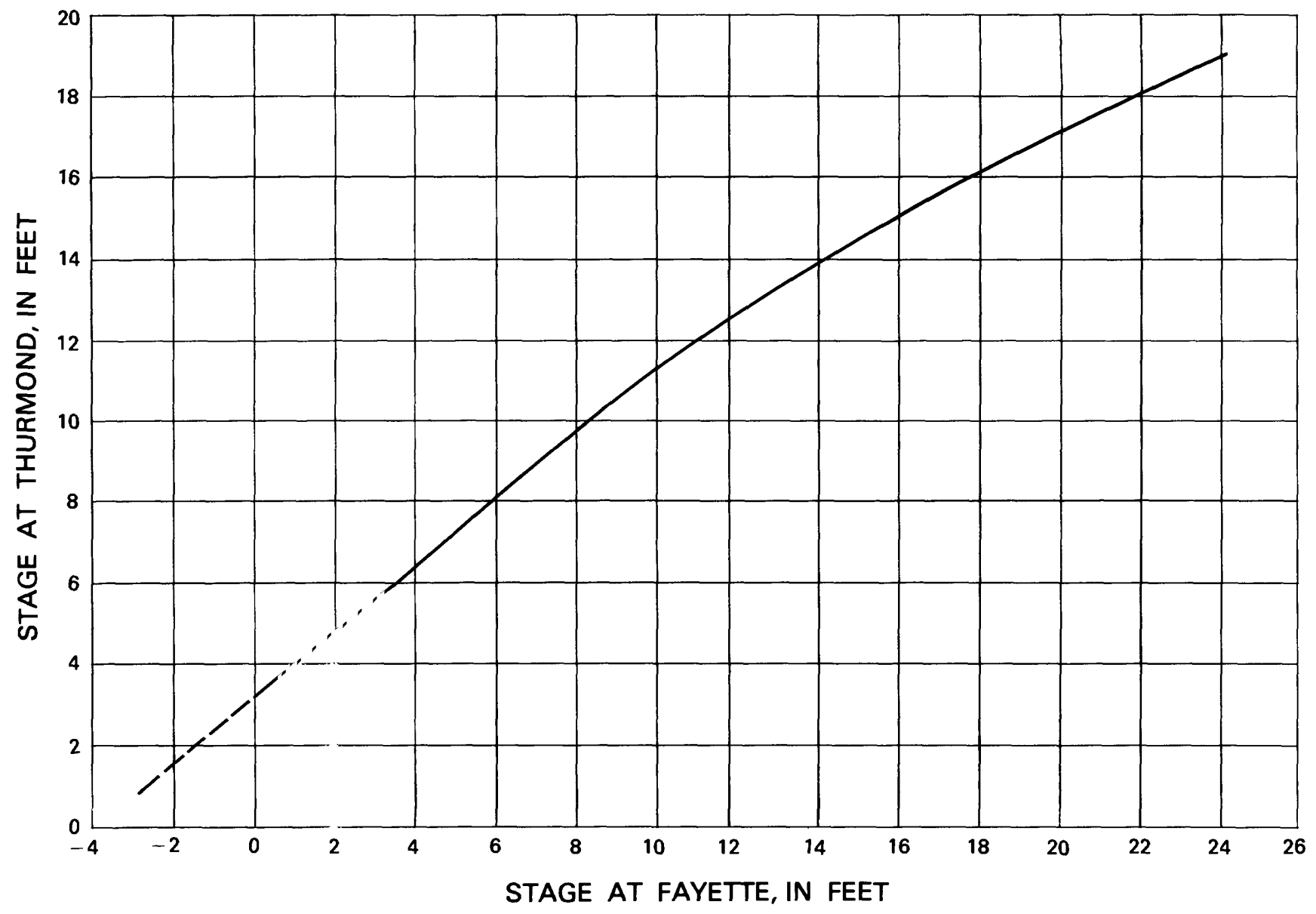

Figure 12. Curve relating river stage at Thurmond and Fayette. 